\title{
Projection of Agricultural Water Stress for Climate Change Scenarios: A Regional Case Study of Iraq
}

\author{
Saleem A. Salman ${ }^{1}$, Shamsuddin Shahid ${ }^{1}{ }^{\oplus}$, Ahmad Sharafati ${ }^{2}{ }^{\circledR}$, Golam Saleh Ahmed Salem ${ }^{3}$, \\ Amyrhul Abu Bakar ${ }^{1}$, Aitazaz Ahsan Farooque ${ }^{4,5}$, Eun-Sung Chung ${ }^{6} \mathbb{D}^{\circ}$, Yaseen Adnan Ahmed ${ }^{7}{ }^{\mathbb{D}}$, \\ Bryukhov Mikhail ${ }^{8}$ and Zaher Mundher Yaseen ${ }^{8,9, *}$
}

1 School of Civil Engineering, Faculty of Engineering, Universiti Teknologi Malaysia (UTM), Johor Bahru 81310, Malaysia; assaleem2@live.utm.my (S.A.S.); sshahid@utm.my (S.S.); amyrhul@utm.my (A.A.B.)

2 Department of Civil Engineering, Science and Research Branch, Islamic Azad University, Tehran, Iran; asharafati@gmail.com

3 Department of Electrical and Electronic Engineering, Trust University, Barishal, Ruiya, Nobogram Road, Barishal 8200, Bangladesh; salemape@yahoo.com

4 Faculty of Sustainable Design Engineering, University of Prince Edward Island, Charlottetown, PE C1A4P3, Canada; afarooque@upei.ca

5 School of Climate Change and Adaptation, University of of Prince Edward Island, Charlottetown, PE C1A4P3, Canada

6 Faculty of Civil Engineering, Seoul National University of Science and Technology, Seoul 01811, Korea; eschung@seoultech.ac.kr

check for

updates

Citation: Salman, S.A.; Shahid, S.; Sharafati, A.; Salem, G.S.A.; Bakar, A.A.; Farooque, A.A.; Chung, E.-S.; Ahmed, Y.A.; Mikhail, B.; Yaseen, Z.M. Projection of Agricultural Water Stress for Climate Change Scenarios: A Regional Case Study of Iraq. Agriculture 2021, 11, 1288. https:// doi.org/10.3390/agriculture11121288

Academic Editors: Fernanda Fidalgo and Conceição Santos

Received: 8 November 2021

Accepted: 9 December 2021

Published: 17 December 2021

Publisher's Note: MDPI stays neutral with regard to jurisdictional claims in published maps and institutional affiliations.

Copyright: (C) 2021 by the authors. Licensee MDPI, Basel, Switzerland. This article is an open access article distributed under the terms and conditions of the Creative Commons Attribution (CC BY) license (https:/ / creativecommons.org/licenses/by/ $4.0 /)$.
7 School of Mechanical Engineering, Faculty of Engineering, Universiti Teknologi Malaysia (UTM), Johor Bahru 81310, Malaysia; yaseen@mail.fkm.utm.my

8 Department of Urban Planning, Engineering Networks and Systems, Institute of Architecture and Construction, South Ural State University, 76, Lenin Prospect, 454080 Chelyabinsk, Russia; briukhovmn@susu.ru

9 New Era and Development in Civil Engineering Research Group, Scientific Research Center, Al-Ayen University, Nasiriyah 64001, Iraq

* Correspondence: yaseen@alayen.edu.iq

Abstract: Assessment of possible changes in crops water stress due to climate alteration is essential for agricultural planning, particularly in arid regions where water supply is the major challenge for agricultural development. This study aims to project climatic water availability (CWA) and crop water demand (CWD) to outline the possible future agricultural water stress of Iraq for different radiative concentration pathways (RCPs). The ensemble means of downscaled precipitation and temperature projections of the selected global climate models (GCMs) were used in a simple water balance model for this purpose. The modified Mann-Kendall (mMK) trend test was employed to estimate the tendency in CWA and the Wilcoxon rank test to evaluate CWD alteration in three future time horizons compared to the base period (1971-2000). The results revealed a decrease in CWA at a rate of up to -34 /year during 2010-2099 for RCP8.5. The largest declination would be in summer (-29/year) and an insignificant decrease in winter (-1.3/year). The study also showed an increase in CWD of all major crops for all scenarios. The highest increase in CWD would be for summer crops, approximately $320 \mathrm{~mm}$, and the lowest for winter crops, nearly $32 \mathrm{~mm}$ for RCP8.5 in the far future (2070-2099). The decrease in CWA and increase in CWD would cause a sharp rise in crop water stress in Iraq. This study indicates that the increase in temperature is the main reason for a large increase in CWD and increased agricultural water stress in Iraq.

Keywords: general circulation models; climate change; crops water availability; trend analysis

\section{Introduction}

Hydrological variations are the most impending and major impacts of anthropogenic climate change [1]. Agriculture's dependence on water resources has made it highly susceptible to climate variability [2,3]. Limited availability of arable land in arid regions 
has made their maximum use for cultivation, and therefore, livelihoods of the majority population depend on agriculture $[4,5]$. Despite the success of agriculture in arid regions, water availability is still the primary barrier to agricultural practices [6,7]. Global warming is supposed to affect the arid region's climate more severely than other climate zones [8-10]. The dry areas of West Asia are believed to be affected more than other areas [11-13]. The temperature of West Asia is increasing much faster than the global average, while a substantial decrease in rainfall is also perceived [14-16]. Iraq is one of the most affected countries in the region due to climate change [17-19]. A decrease in climatic water availability (CWA) and an increase in crop water demand (CWD) are already evident in the country [7]. The anticipated changes in the future climate from GCM simulations indicate a continuous rise in CWD and declination in CWA in Iraq, which may cause severe water scarcity in this already water-stressed country and risk to the livelihood of agriculture-reliant large inhabitants $[20,21]$. Streamlining the governmental policies for building a climate-resilient society is vital for people's well-being in Iraq. A better understanding of the ongoing changes and the probable future variability in water availability and demand is essential for formulating effective strategies to combat the growing water stress.

Atmospheric water balance and crop water requirements are principally dependent on the precipitation amount and potential evapotranspiration [22-24]. These two climate variables decide hydrologic budgets at varying scales [25]. In 1948, Thornthwaite first defined the principles of atmospheric water balance and applied the same for CWA and CWD estimation [26]. CWA is mainly useful in analyzing water resource availability and droughts [27-29]. It significantly influences biological diversity and ecological variability [30]. Higher CWA increases the crop growing period and helps in better crop growth, and enhances productivity [31]. Therefore, it is a critical determinant of the productivity of different crops of a region. CWA is also an indicator of potential drought stress [32]. The high variability of CWA indicates high fluctuation of precipitation and potential evapotranspiration (PET), and thus, the susceptibility of a region to hydrological hazards [7].

The CWD provides a rough measure of water availability and agricultural water needs. Therefore, it indicates water abundance or scarcity in a region [33,34]. It is also the deciding factor of crop water efficiency, and thus, a measure of climate resiliency and sustainability of agriculture [1]. Plausible changes in CWD in the near and far future are essential for water resources planning. It is also important for irrigation rescheduling and sustainable agriculture management under changing environments. Due to limited availability, uninterrupted water supply augmentation is not possible. Therefore, irrigation demand management would be the key option for climate change adaptation to water resources [1]. Projection of CWD can help decide the needed control of irrigation demand for climate resilience water management [35]. Therefore, estimation of probable alterations in CWA and CWD are important for understanding the possible changes in water stress, ecology, crop productivity, and hazard susceptibility of a region.

Several studies have assessed the atmospheric water balance to recognize the climate influence on CWA and CWD in different regions of the world [28,36-41]. Few studies have also been conducted on the possible change in precipitation and water availability in the Arabian Peninsula [42-44]. However, no study has focused on a detailed assessment of the influence of future climate variability on CWA and CWD during crop growing seasons in the highly vulnerable arid region of West Asia. The possible effect of climate variability on CWA and CWD and thus impending water stress in predominantly arid Iraq was quantified in this study. The downscaled GCMs simulations were used in a simple water balance model to evaluate possible alterations in CWA and CWD. The non-parametric MannKendall (MK) test is generally used for trend assessment $[14,45,46]$. It has been observed that the trend significance substantially changes by the autocorrelation in data series [45]. Therefore, an improved version of the MK test (mMK) was employed for unbiased estimation of the changes in water availability [46]. Besides, the non-parametric Wilcoxon rank test was used to measure the difference in climate variables for different periods $[4,7]$. The methodical 
framework presented in this study can be employed for similar analysis in any other region to aid policy formulation for improving climate resiliency in agriculture.

\section{Case Study and Data Description}

\subsection{Iraq Region Climate Characteristics}

Iraq, situated in the south of West Asia, covers a land area of $438,320 \mathrm{~km}^{2}$. The geographical location of the country is presented in Figure 1. Summer and winter are the major seasons of Iraq. The summer starts in June and ends in September, and the winter begins in November and ends in March [47,48]. Almost all rainfall (nearly 90\%) occurs in winter, and therefore, the summer is extremely dry [49]. The amount of rainfall in Iraq varies according to regions; the southwestern part of Iraq receives $<100 \mathrm{~mm}$ annual rainfall while the northern part receives more than $1000 \mathrm{~mm}$ annually [50]. Iraq records the lowest temperature of about 0 to $5^{\circ} \mathrm{C}$ in winter in the northeast mountains while the summer daytime temperature is usually $>45^{\circ} \mathrm{C}$ in the south [51]. Most of Iraq experiences a subtropical desert climate (BWh), followed by sub-tropical steppe (BSh) and dry summer sub-tropical (Csa) climates, as depicted in Figure 1. Owing to the collective impacts of extreme temperature and low rainfall, most of the country is extremely dry. Furthermore, Iraq is highly prone to natural disasters due to a larger variability in climate [19].

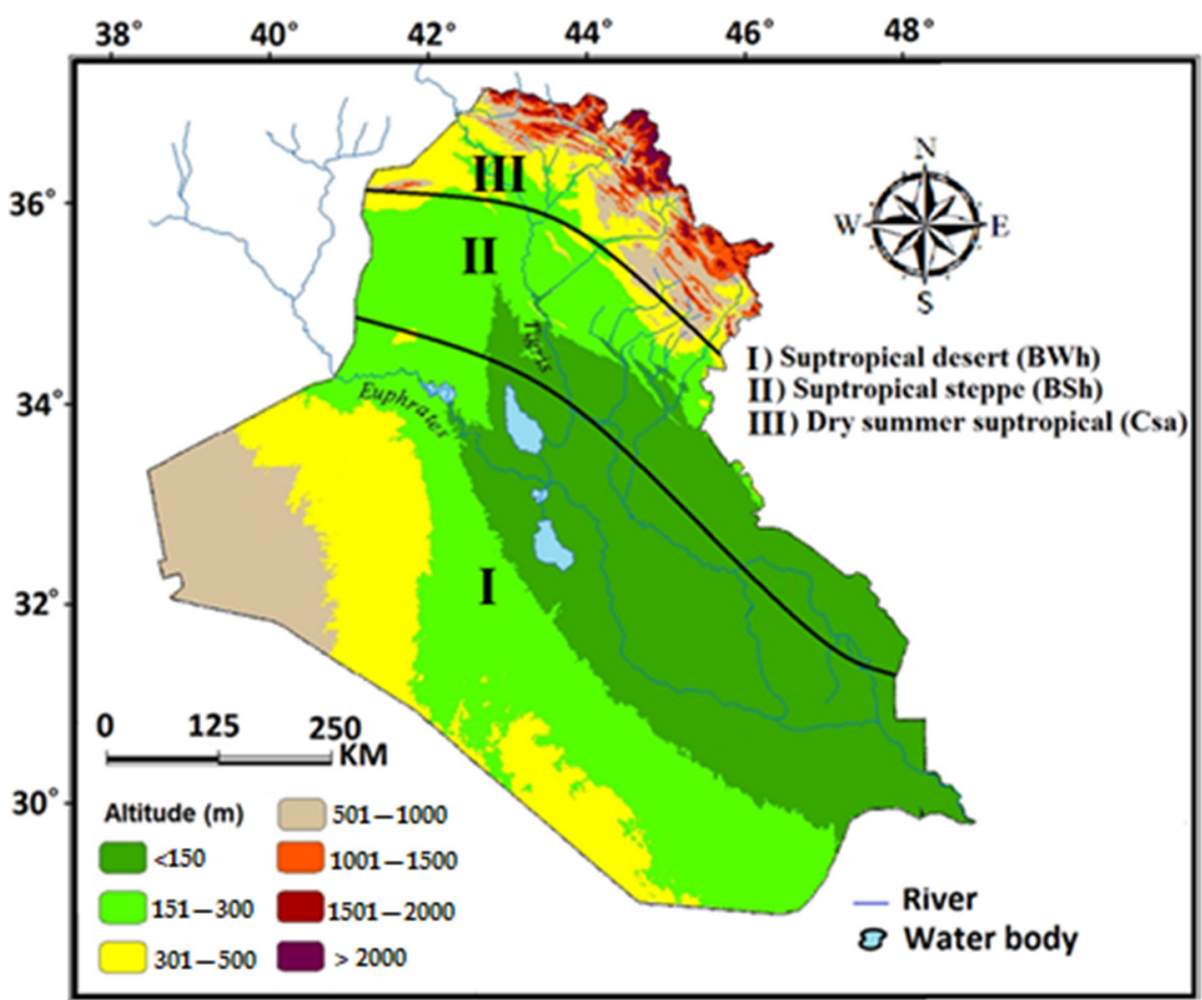

Figure 1. The altitude and climate regions of Iraq.

\subsection{Agricultural Lands of Iraq}

The country's agriculture heavily depends on the water supply of two main rivers: Euphrates and Tigris [52]. Therefore, nearly $70 \%$ of the arable lands in the country lies in the central and southeast region along the major rivers, where crop production is mainly dependent on irrigation schemes (Figure 2). The remaining 30\% of cultivated lands are mostly in the northern region and are grown under rain-fed [53]. 


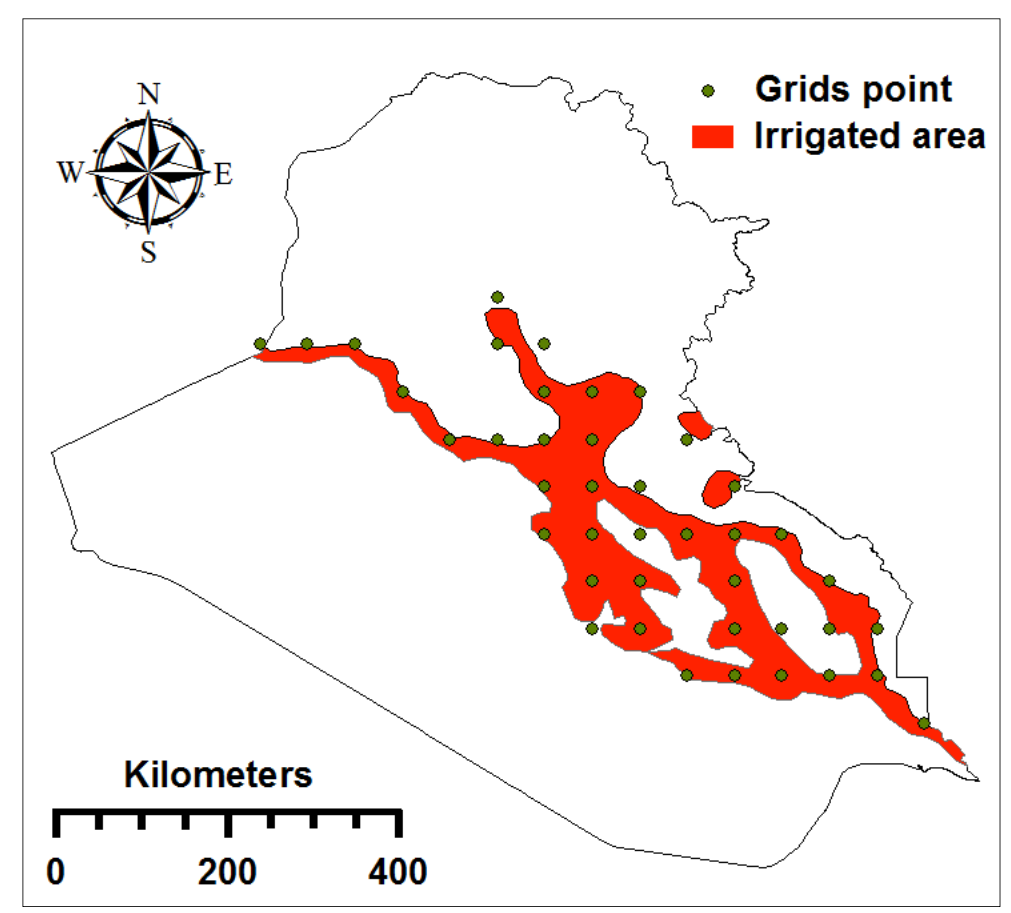

Figure 2. Irrigated area in Iraq and the grids points at which climatic water availability and crop water demand were estimated.

\subsection{The Crop Growing Seasons}

Five major crops of Iraq were considered in this study, which includes two winter crops, wheat (Triticum aestivum) and barley (Hordeum disticum), and three summer crops, millet (Panicum miliaceum), sorghum (Sorghum halepense), and potato (Solanum tuberosum). The winter crops are cultivated in nearly $70 \%$ of the cultivated land, while the rest is used for summer crops. The sowing to harvesting periods of the crops are presented in Figure 3. The present study assessed the climate change impacts on CWD for one major crop in each season. CWDs of other crops of the same season are similar, and therefore, not presented to avoid repetition. The crop needs water until the end of the growing stage. Therefore, the CWDs for the sowing and growing periods were analyzed in this study.

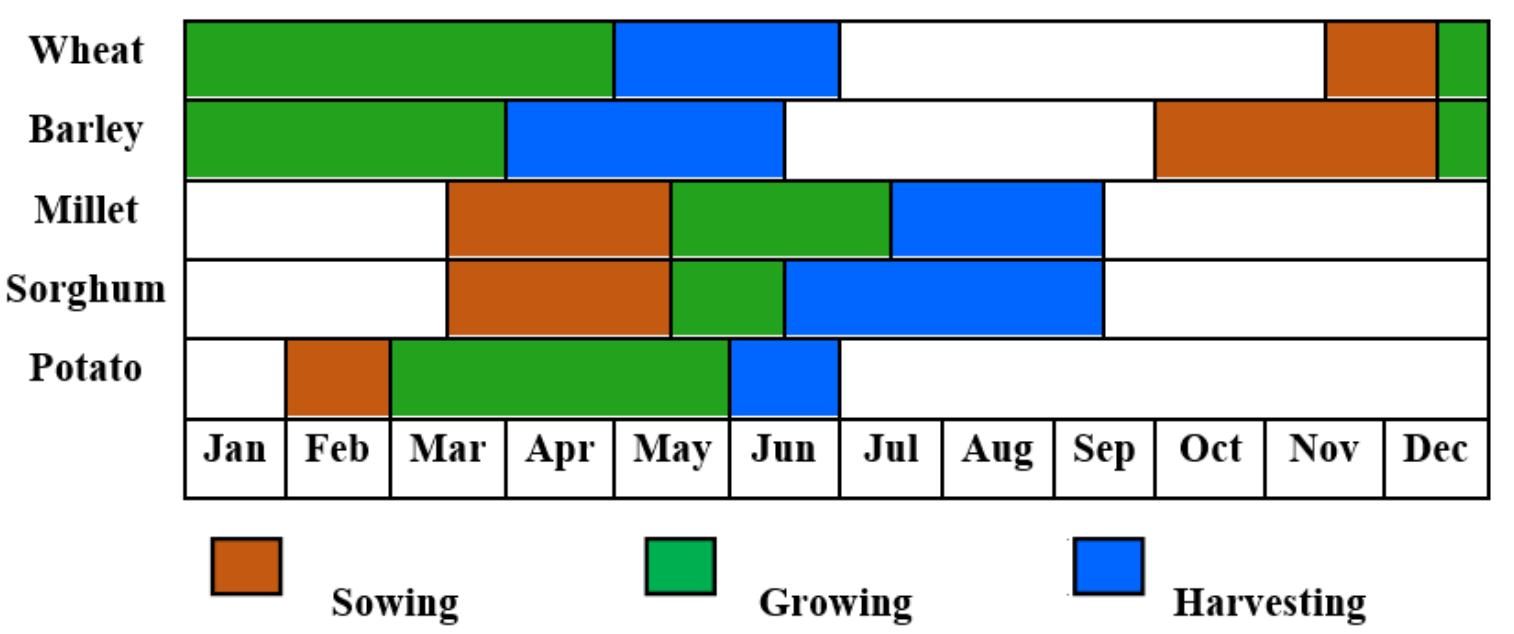

Figure 3. The crop seasons for the Iraq region. 


\subsection{Climate Data}

\subsubsection{Gridded Rainfall and Temperature}

The monthly precipitation of global precipitation climatology Centre (GPCC) and mean temperature of Climatic Research Unit (CRU) gridded at a resolution of $0.5^{\circ}$ were extracted for the period 1971-2000 to be used as reference data for the estimation of climate change impacts on CWD. Literature review suggests GPCC and CRU as the best datasets for assessing the region's climate $[4,14]$.

\subsubsection{GCM Data}

Four GCMs, HadGEM2-AO, HadGEM2-ES, MIROC5, and MIROC-ESM, were employed in this study. Salman et al. [54] compared the suitability of CMIP5 GCMs for Iraq using different performance indices. They reported these four GCMs as the best for climate change projection of the country [55]. Details of the GCMs are given in Table 1. Simulations of these four GCMs for all the four RCPs were employed to understand the range of climate change impact on water stress.

Table 1. Description of the global climate model employed in this study.

\begin{tabular}{cccc}
\hline No & GCM & Developing Institute & $\begin{array}{c}\text { Resolution } \\
\text { (Lon } \times \text { Lat) }\end{array}$ \\
\hline 1 & HadGEM2-AO & National Institute of Meteorological Research, South Korea & $1.87^{\circ} \times 1.25^{\circ}$ \\
$1.4^{\circ} \times 1.4^{\circ}$ & $2.8^{\circ} \times 2.8^{\circ}$ \\
3 & MIROC5 & Japan Agency for Marine-Earth Science and Technology, & $1.87^{\circ} \times 1.25^{\circ}$ \\
4 & MIROC-ESM & Japan & Met Office Hadley Centre, UK \\
\hline
\end{tabular}

Salman et al. [54] downscaled the selected GCMs at a resolution of $0.5^{\circ}$ using GPCC and CRU data. The ensemble mean of the projected average temperature and rainfall were used for CWA and CWD change analysis. Projected changes in the ensemble mean temperature during 2070-2099 compared to the CRU temperature for the period 1971-2000 (base period) in the three climate zones of Iraq for four RCPs are presented in the left panel of Figure 4. The figure shows the projected ensemble mean rainfall for different months during 2070-2099 in different climate zones for different RCPs and GPCC precipitation for the base years.

The temperature showed a rise in all months and RCPs, with a higher increase in summer than winter. Rainfall showed an increase in winter while no variation in summer for all RCPs. The temperature rise was projected to be higher in Zone-I, whereas the rainfall increases more in Zone-III in winter. 

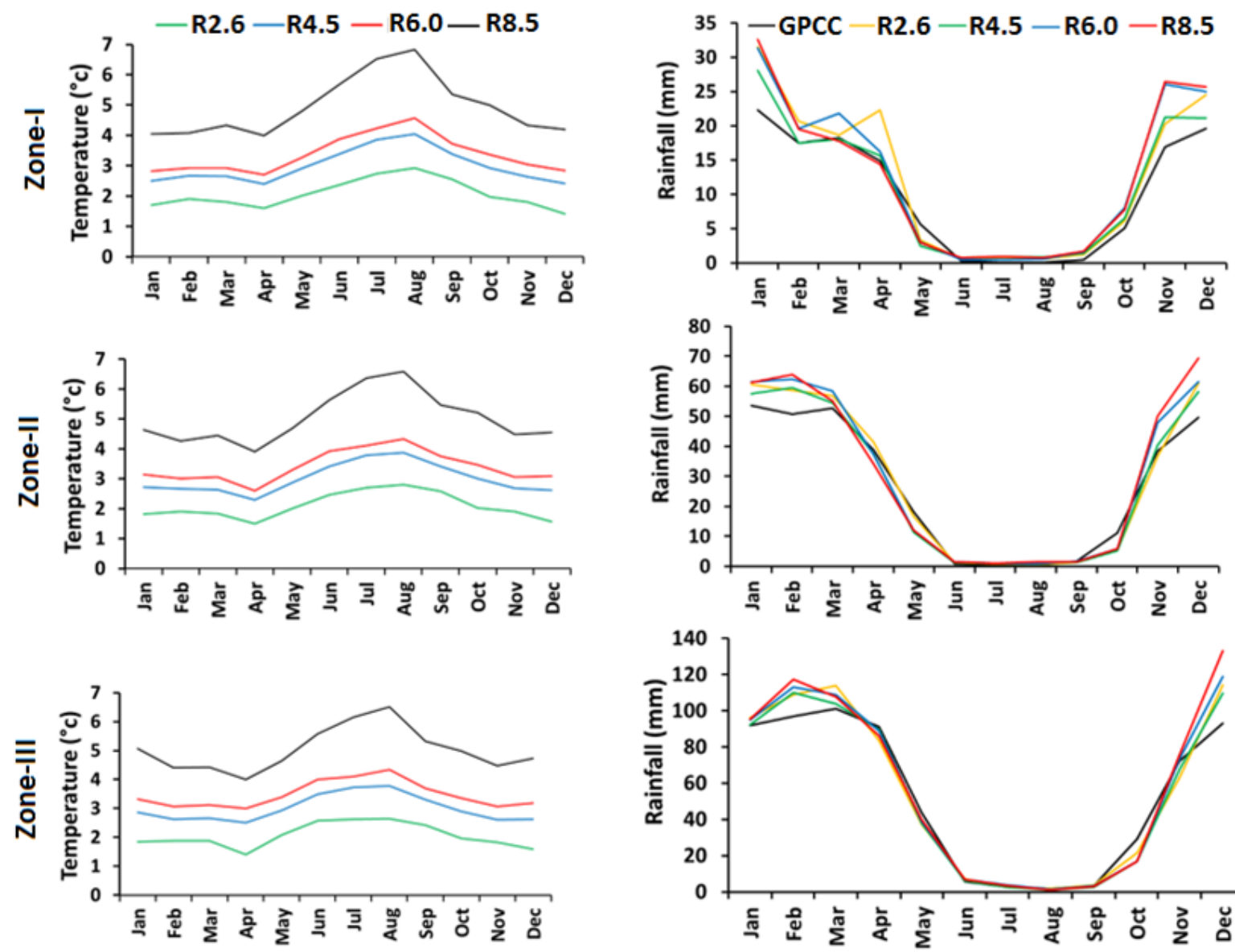

(a)

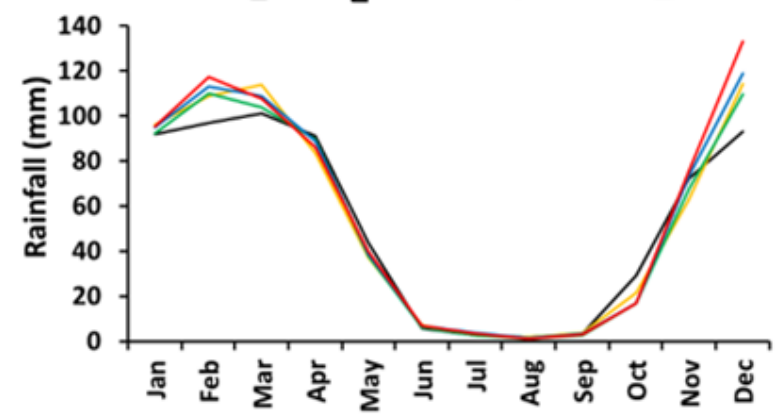

(b)

Figure 4. Projection of (a) temperature changes and (b) rainfall amount in different climate zones of Iraq during 2070-2099 for four RCPs.

\section{Methodological Overview}

\subsection{Climatic Water Availability (CWA)}

The CWA is the available water after losses through evapotranspiration. Thus, the estimation of the $\mathrm{CWA}_{i}$ of the month, $i$ is done as follows:

$$
\mathrm{CWA}_{i}=P_{i}-\mathrm{PET}_{i}
$$

where $P_{i}$ and $\mathrm{PET}_{i}$ are the rainfall and PET of $i$-th month. The Thornthwaite method was employed for PET estimation, considering that only the mean temperature projections are available for future periods. Thornthwaite PET is estimated [56] as:

$$
\mathrm{PET}_{i}=16 K_{i}\left(\frac{10 T_{i}}{H}\right)^{m}
$$

where $T_{i}$ is the average monthly temperature $\left({ }^{\circ} \mathrm{C}\right)$ and $K_{i}$ represents the correction coefficient for the i-th month. Note that the Thornthwaite method overestimates PET [57]. However, it will not affect the results as the relative changes in CWA and CWD were evaluated in this study, nullifying the biases in estimated PET by the Thornthwaite method.

\subsection{Crop Water Demand (CWD) Estimation}

The FAO-56 model [58] can be used for the estimation of CWD as follows:

$$
\mathrm{CWD}=E T_{\text {crop }}-P_{e}
$$


where $E T_{\text {crop }}=$ crop evapotranspiration and $P_{e}=$ effective precipitation. The $E T_{\text {crop }}$ is estimated thus:

$$
E T_{\text {crop }}=K_{c} \times E T_{o}
$$

where $K_{c}$ represents the crop coefficient. The FAO suggested $K_{c}$, as presented in Figure 5 [59], was adopted to estimate CWD in this study.
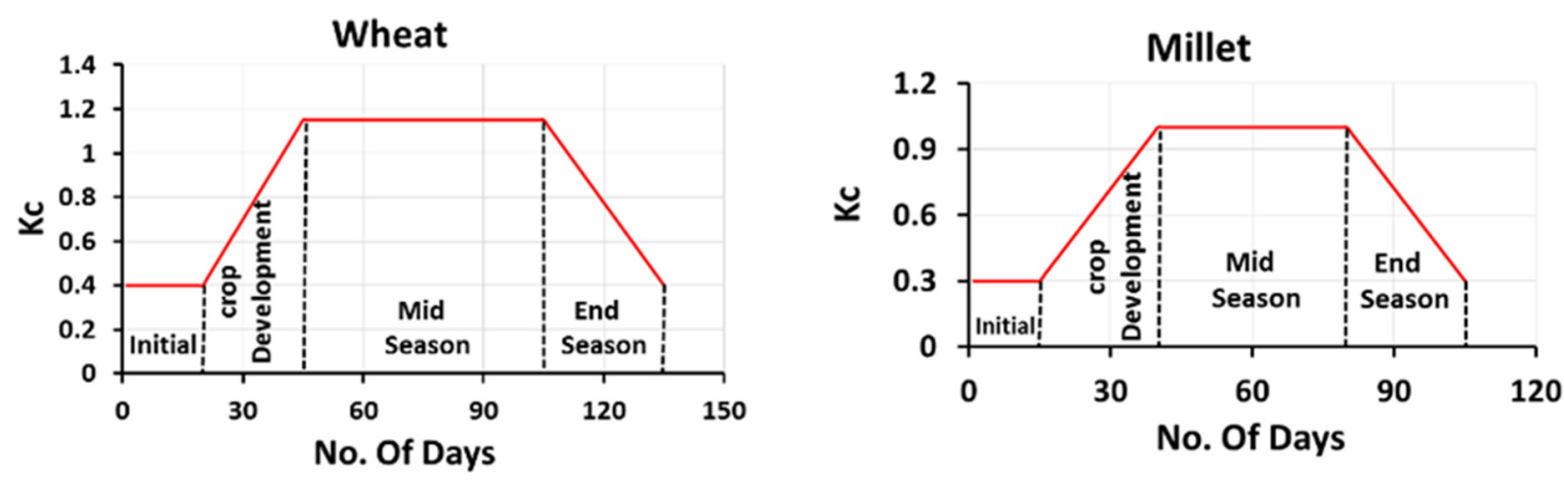

Figure 5. The crop coefficients of major summer (wheat) and winter (millet) crops.

\subsection{Change Assessment}

The Sen's slope $(Q)$ calculates the change in CWA as [60]:

$$
Q=\text { median }\left[\frac{\Delta y}{\Delta t}\right]
$$

where $\Delta y$ is the difference between two consecutive CWA due to the difference in time, $\Delta t$.

The significance of $Q$ is estimated using the mMK test, where the CWA series is first detrended if found significant using the classical MK test. The series is then ranked to estimate the normal variants to determine the Hurst coefficient $(H)$ and estimate the auto-correlation function. For significant $H$, the variance of the series is estimated, and its bias is corrected for significance assessment using Z-statistics. The article of Hamed (2008) can be consulted for details [46]. Changes at a significance of $0.05(p=0.05)$ were used in this study.

\subsection{Wilcoxon Signed-Rank Test (WS)}

The non-parametric WS test [61] was employed to estimate the significant change in CWD in the future for different RCPs against the base period (1970-2000). The WS test can be employed without considering the distribution and sample size of CWD. The WS test ranks the CWD values for both periods and calculates the absolute differences to estimate WS test statistics (W), which are subsequently used to calculate Z-statistics for significance estimation. The null hypothesis of the WS test is CWD in the base and future periods have the same median, meaning no change in CWD if the null hypothesis is rejected [62].

\section{Modelling Results and Analysis}

\subsection{Trends in Climatic Water Availability}

Ensemble mean projections of rainfall and temperature were employed to assess the probable future changes in CWA in Iraq for the period 2010-2099. Trends in winter and summer CWA for different RCPs during 2010-2099 are displayed in Figures 6 and 7, respectively. The colors in the maps indicate the amount of change in CWA, and the sign $(+$ or -$)$ specifies an increase or decrease in CWA estimated by the mMK test at $p=0.05$. 


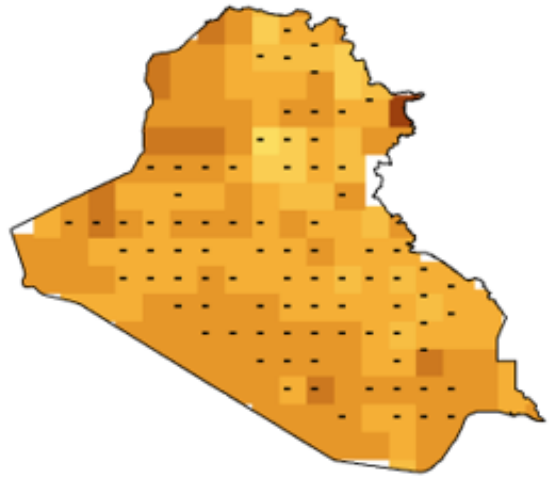

RCP 2.6

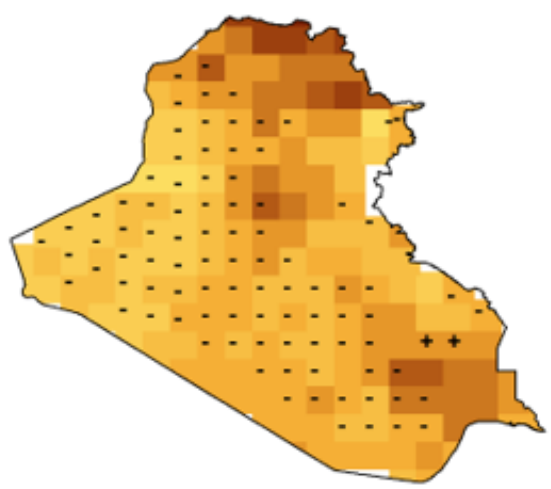

RCP 6.0

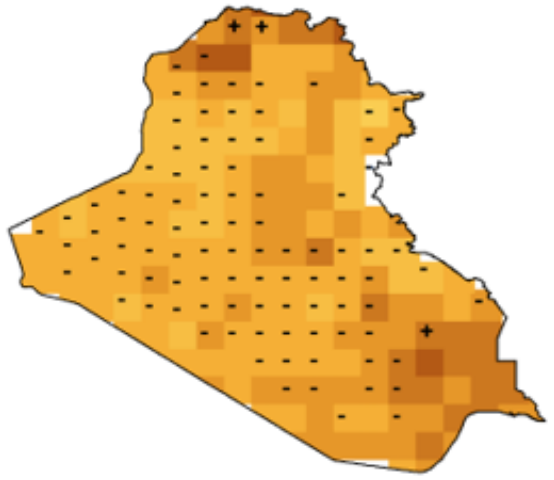

RCP 4.5

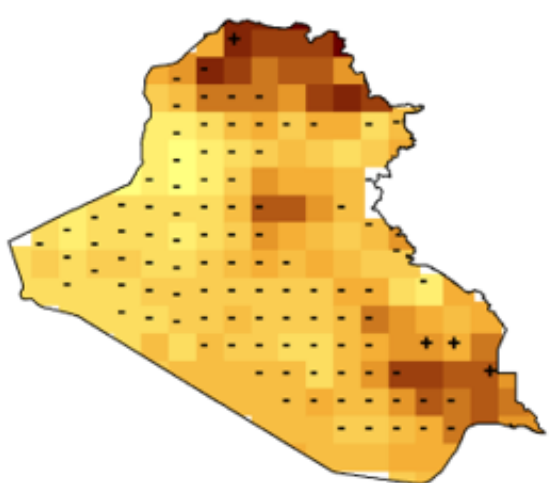

RCP 8.5

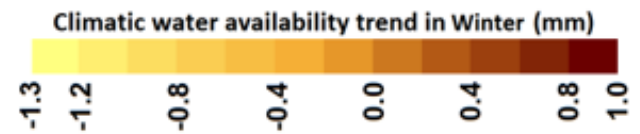

Figure 6. Spatial variations of winter CWA trends for different RCPs during 2010-2099, the sign $(+$ or -$)$ specifies an increase or decrease in CWA estimated by the mMK test at $p=0.05$.

A decreasing winter CWA at $p=0.05$ was noticed in most of the regions for all the RCPs. The decrease was highest in central Iraq by -0.8 to $-1.3 \mathrm{~mm} /$ year and the lowest in the northern steppes and the southern coast by -0.1 to $-0.4 \mathrm{~mm} /$ year for all the RCPs. The winter CWA was also noticed to increase at a few grids in the far south and in the north for RCPs 6.0 and 8.5 by $0.8-1.0 \mathrm{~mm} /$ year.

The summer CWA was found to decrease faster than winter CWA (Figure 7). The decrease was found to be significant at $p=0.05$ for all RCPs for almost all of Iraq. The decrease was found to be more than $20 \mathrm{~mm}$ /year in most of Iraq for RCP8.5, while it was found to be less than $5 \mathrm{~mm} /$ year for RCPs 2.6 and 4.5. The decrease was found to be higher in the central region and relatively less in the north for all RCPs. Summer CWA was not observed to increase at any grid. 

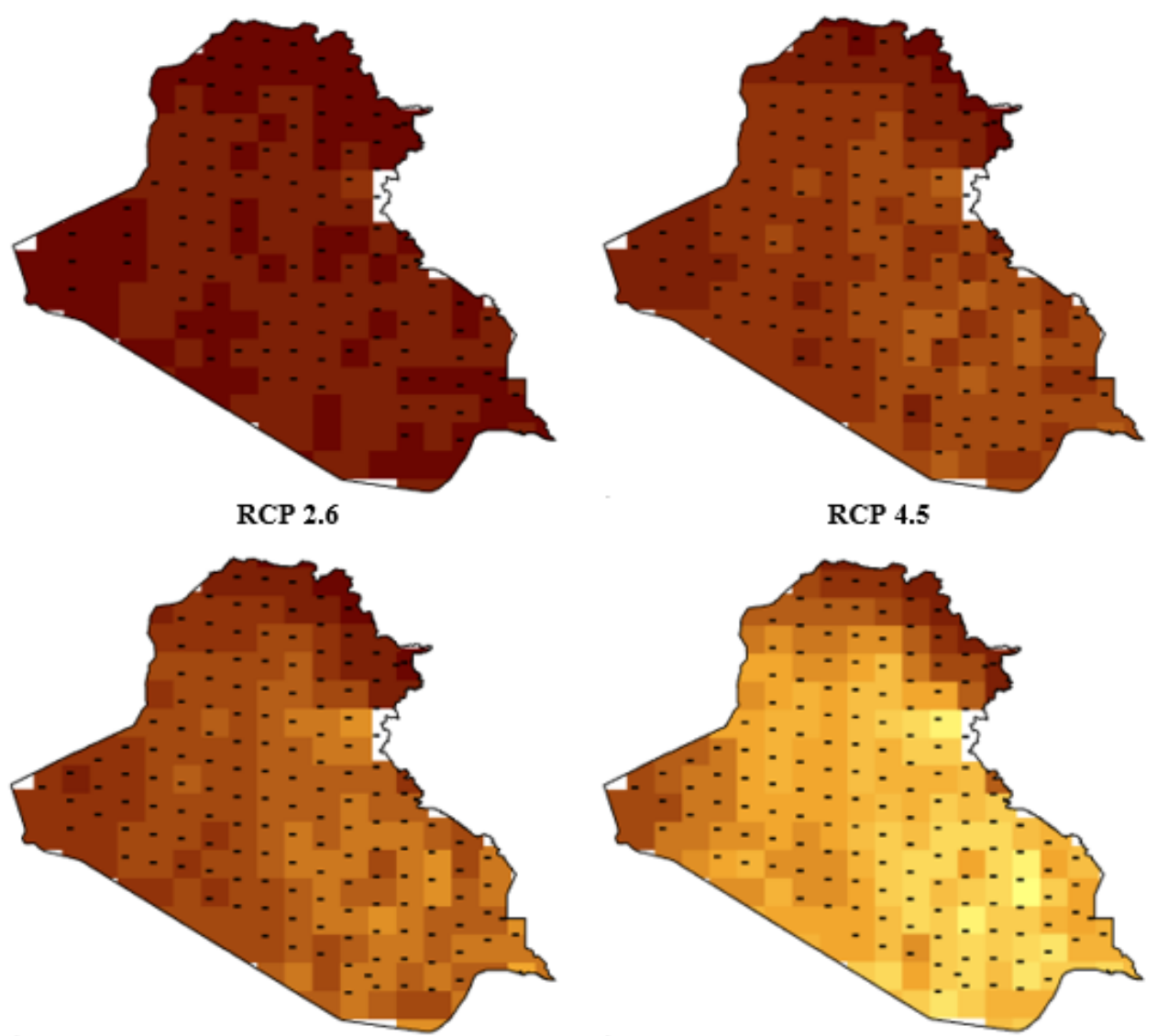

RCP 6.0

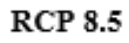

Climatic water availability trend in Summer (mm)

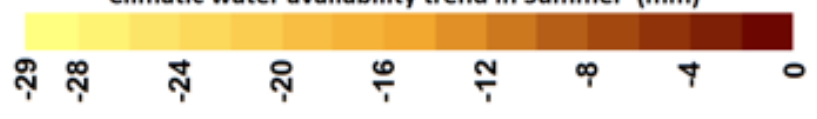

Figure 7. Spatial variations of summer CWA trends for different RCPs during 2010-2099, estimated using the mMK test at $p=0.05$.

\subsection{Geographical Distribution in CWD Changes for Winter and Summer Crops}

Projected changes in CWD in future periods compared to the base period (1971-2000) were estimated for both winter and summer crops. However, the geographical distribution of the changes in the far future (2070-2099) only shows the maximum possible changes. The results for the winter crop (wheat) for four RCPs are presented in Figure 8. The diameter of the dots in the maps represent the volume of CWD change. The CWD for wheat was noticed to increase for all RCPs for the entire cultivated areas. The highest increase was observed to be 13-15 and 16-18 $\mathrm{mm}$ in the south for RCP 2.6 and 4.5, respectively; 16-21 $\mathrm{mm}$ in the southwest for RCP 6.0; and 31-35 mm in the southwest for RCP8.5. A higher increase was observed for higher RCPs and vice versa. The water demand showed a relatively less increase for wheat in the northeast for all RCPs. 


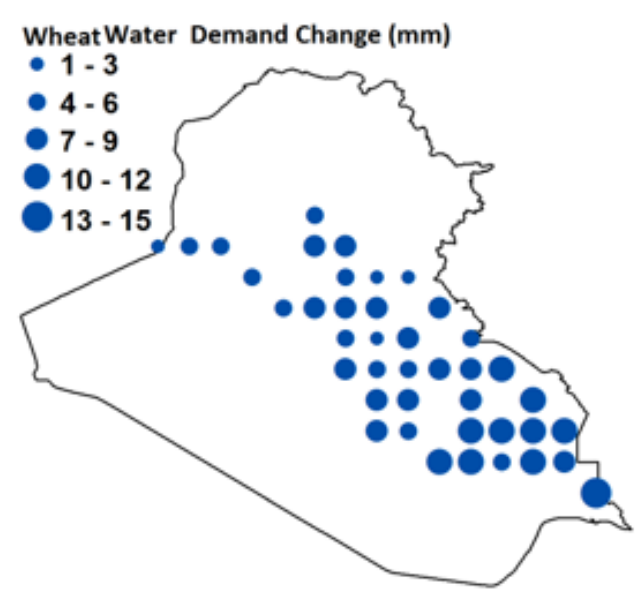

RCP 2.6

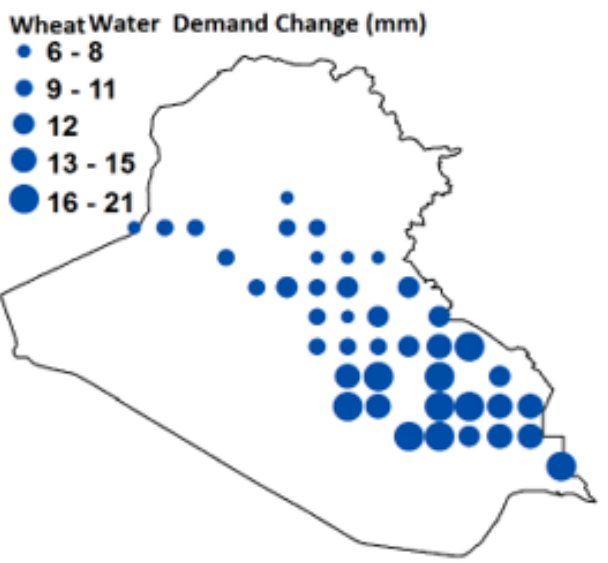

RCP 6.0
Wheat Water Demand Change $(\mathrm{mm})$

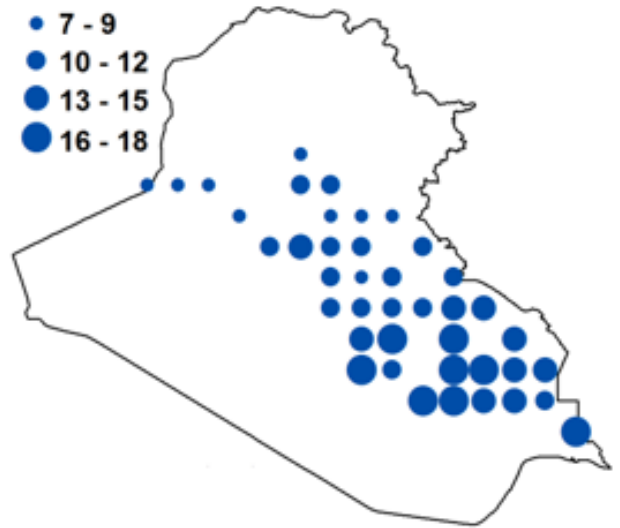

RCP 4.5

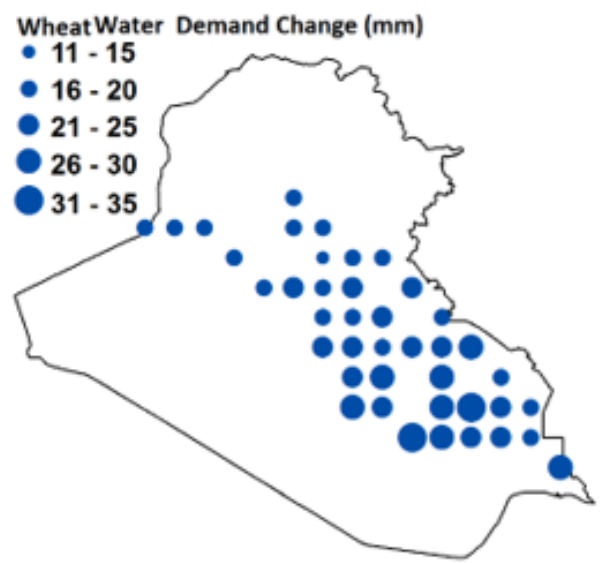

RCP 8.5

Figure 8. The geographical variations of the changes of water needs for wheat between 2070 and 2099 and 1971 and 2000 for four RCPs.

Compared to winter crops, water demand for summer crops (e.g., millet) showed a much higher increase for all RCPs (Figure 9). The CWD for millet was also projected to increase by 101-120, 151-175, 181-210, and 281-320 $\mathrm{mm}$ in the southeast of the irrigation region for RCPs 2.6 to 8.5, respectively. The increase was found to be relatively less in the northwest, in the range of 36-40, 60-75, 66-90, and 126-160 mm for RCPs 2.6 to 8.5, respectively. 

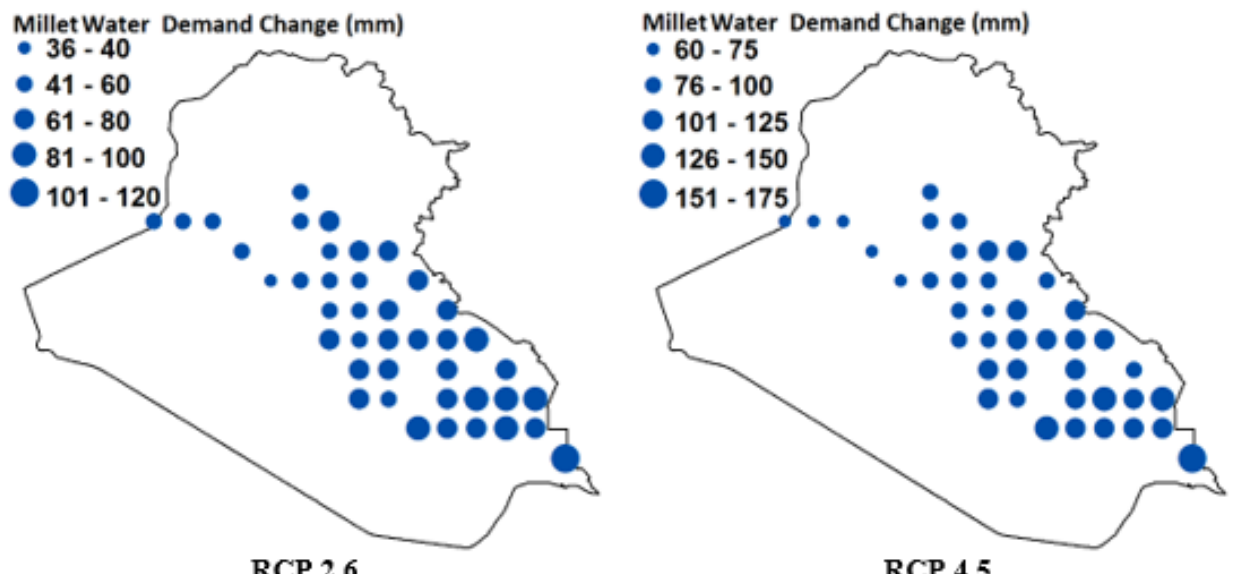

RCP 4.5

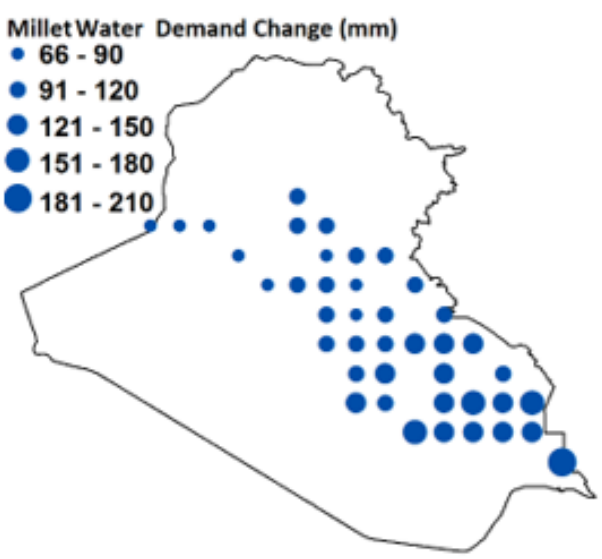

RCP 6.0

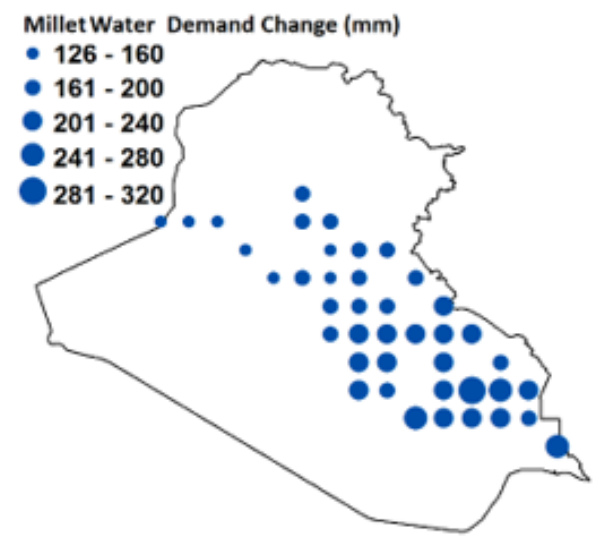

RCP 8.5

Figure 9. The geographical variations of the changes of the water needs for millet between 2070 and 2099 and 1971 and 2000 for four RCPs.

\subsection{Monthly Changes in CWD}

The CWD changes for different growing months of wheat and millet in three future time horizons with respect to the base period were estimated. The significance of the change between the two periods was estimated using the WS test. The results obtained for wheat are presented in Figure 10. A negative value of CWD indicates rainfall is sufficient to compensate for the evaporative losses, and thus, there are no irrigation requirements. Therefore, the months with no irrigation need are not shown in the figure. The changes in CWD for four RCPs in the base period, 1961-1990 (blue), and three future periods, 2010-2039 (yellow), 2040-2069 (red), and 2070-2099 (black), are shown in the figure. The sign ' + ' above the bar indicates the change is significant by the WS test at $p=0.05$.

Figure 10 shows the highest increase in wheat's water needs in April followed by March. The increase was found to be significant for April during 2040-2069 for all scenarios. A significant increase in CWD in both March and April in the far future (2070-2099) for RCPs higher than 4.5 was also observed. Overall, the increase in CWD in March and April was found to increase with time and RCPs. Changes in CWD in the rest of the four months (November to February) were found to be insignificant for all future periods and RCPs.

A large and significant increase in CWD for most of the months of the millet growing period was observed (Figure 11). The largest rise was noticed in June by 490 to $789 \mathrm{~mm}$ for the different RCPs. The increase was found to be higher for higher RCPs. A large increase in CWD was also observed for May and July. The WS test estimated the changes significant for May to July in the middle and far futures for all RCPs. The changes in CWD in March and April were not significant for any future periods and RCPs. 

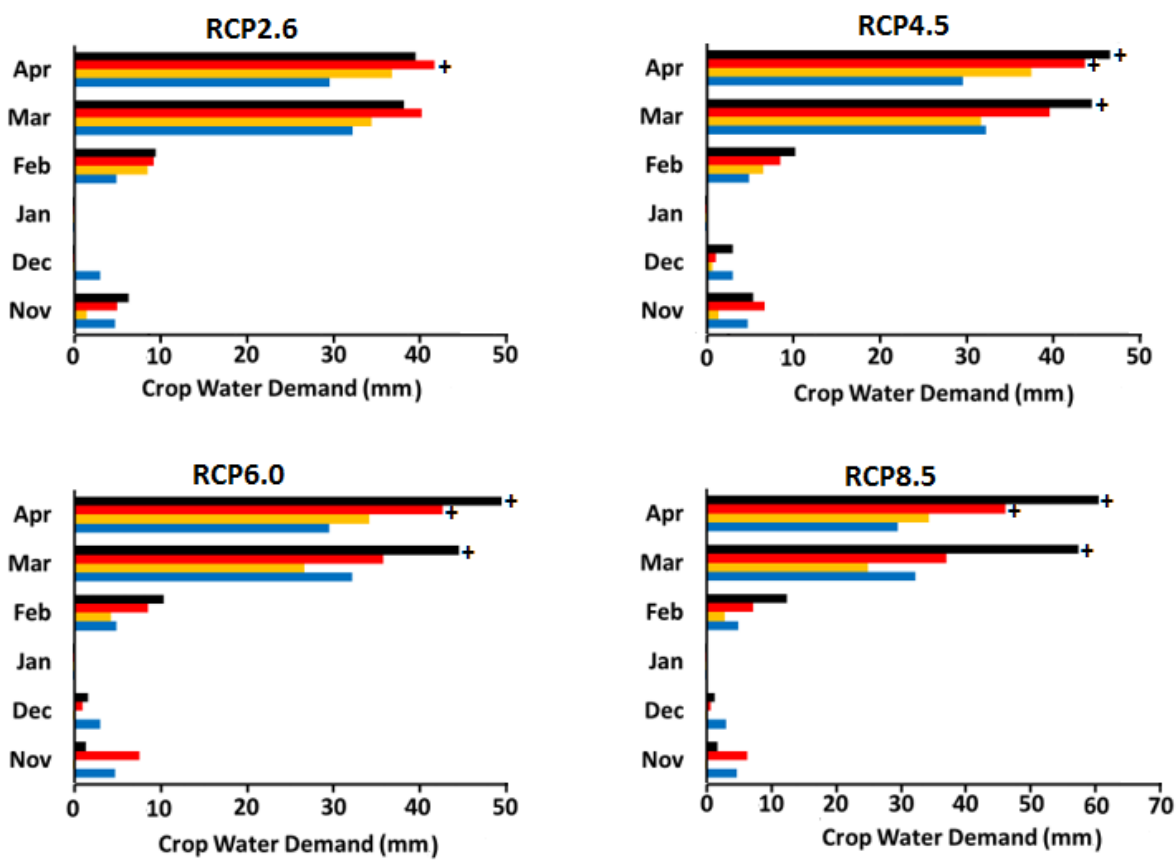

2070-2099 2040-2069

2010-2039

1971-2000

Figure 10. Wheat CWD in the different months of the crop season during 2010-2039 (yellow), 20402069 (red), and 2070-2099 (black) and the base year 1961-1990 (blue) and (+) indicates significant change at $p<0.05$.
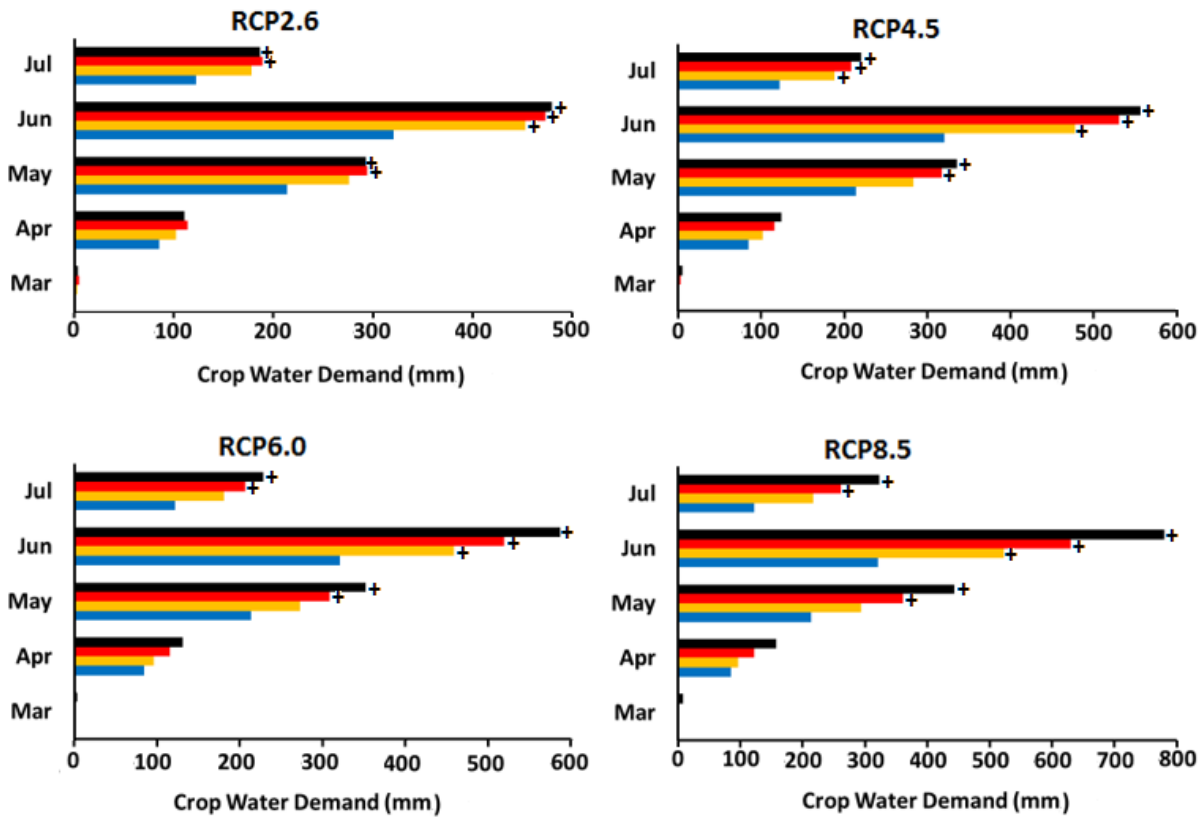

2070-2099 $\quad$ 2040-2069

2010-2039 1971-2000

Figure 11. Millet CWD in the different months of the crop season during 2010-2039 (yellow), 20402069 (red), and 2070-2099 (black) and the base year 1961-1990 (blue) and (+) indicates significant change at $p<0.05$. 


\section{Discussion}

This study projected a significant decrease in CWA in the future for all of Iraq. Recently, Salman et al. (2020) [7] revealed a decrease in CWA in Iraq in recent years. They mentioned that a large increase in temperature and no change in precipitation are the main reasons for decreasing CWA in Iraq. Interpretation of the GCM simulations revealed an unceasing rise in temperature at a high rate in Iraq [13]. This will cause a continuous decrease in CWA in the country in the future. Increased evaporative losses also caused an increased CWD demand in Iraq. The results of this study indicate a large increase in CDA in summer and very little in winter. A large increase in the summer temperature but almost no variation in rainfall will cause a large increase in summer CWD. The winter CWD will also increase due to the rise of temperature, but it will be offset by increased rainfall in some winter months in the future. Therefore, the water needs of winter crops will increase relatively less compared to summer crops. Overall, the results revealed that rising temperature would play a major role in Iraq CWD in the future. The region's temperature is rising rapidly compared to the rest of the globe [15,19], while the rainfall changes are not significant $[13,16]$. A large evaporative loss due to higher temperatures would control the water balance and CWD in Iraq.

The results showed good consistency with that obtained in arid regions of nearby countries and other parts of the globe. Shen et al. (2013) [63] evaluated the spatiotemporal changes in CWD in northwestern China and showed an increase in CWD in recent years. They concluded that April and May are the months with the greatest water deficit. Ragab and Prudhomme (2002) [64] found a decline in water availability due to higher precipitation declination in Iraq than in the other Middle Eastern countries. Climate change implications on the future CWD of Saudi Arabia, which borders with Iraq in the southwest, were investigated by Chowdhury et al. (2016) [42]. The study reported a temperature rise by $1(\mathrm{C})$, which would cause a $2.9 \%$ increase in overall CWD. The impact of rainfall was also reported to be low on CWD compared to that of temperature. It is similar to the outcome of the present study, wherein a large temperature rise was found as the reason for the CWD increase. Rezaei Zaman et al. (2016) [40] employed a hydrological model and reported a decrease in inflow into Lake Urmia (bordering northeast of Iraq) and the consequential decrease in agriculture production by up to $50 \%$. Using a similar hydrological tool in northwest Iran, Azad et al. (2018) [44] demonstrated that an increase in PET due to the temperature rise would affect CWD and eventually reduce crop yield by $24.1 \%$. Zamani et al. (2017) [43] also reported a higher risk in agriculture due to higher CWD in southwest Iran due to climate change.

Climate change projections are associated with large uncertainty. The multimodel ensemble mean of the best-performing GCMs of Iraq was used in this study to provide reliable projections of CWA and CWD. However, Salman et al. [13] showed a large uncertainty in temperature projections for different scenarios using the selected models. This indicates the projected CWA and CWD are also associated with uncertainty. In the future, CWA and CWD can be projected using individual GCMs to estimate the ensemble mean and the associated uncertainty in CWA and CWD projections. The present study also considered no change in $\mathrm{Kc}$ in the future. However, Kc may change in the future due to climate change. The length of crop growth stages may also vary in the future due to temperature changes [3]. The variation in CWD due to possible changes in Kc or crop growing stages was ignored in this study.

Despite the uncertainty, the present study revealed a large increase in water demand for major crops in Iraq. The country should use smart irrigation systems to increase water efficiency to mitigate the climate change impacts on CWD [65]. Farmers should be encouraged to use modern technologies like drip irrigation, need-based irrigation considering soil moisture, enhancing soil water-holding capability using organic matters, and planting cover crops to adapt to the changing climate. The native crop species of Iraq are naturally adaptive to the large climate variability of arid regions. Therefore, 
the cultivation of indigenous species of crops should be encouraged for adaptation to climate change.

\section{Conclusions}

The possible implications of climate variability on water availability and crop water demand were evaluated in this study. Overall, the results pointed out a severe implication of climatic changes on water availability and demand in Iraq. The future projections of CWA and CWD showed the continuation of ongoing declination of CWA and an increase in CWD for all RCPs for the entire agriculture region of Iraq. The impact will be relatively less in the north and higher in southern Iraq. The effect was also found to increase with time and RCPs. A faster temperature rise is the main reason for decreasing CWA and increasing CWD. A higher rise in temperature and almost no increase in rainfall would cause a huge increase in summer CWD in Iraq. However, the impact will be relatively less in winter due to an increase in winter rainfall. This country needs to streamline the existing strategies for building climate resiliency in water resources. Some of the high potential strategies including turning wastewater into a valuable resource, increasing water productivity, and increasing virtual water trade can be adopted. Besides, water supply enhancement through dams and subsurface storage through recharge augmentation should be considered. Major emphasis should be given to water demand management through water pricing, water regulations, adoption of water-saving techniques, appropriate crop selections, and farm practices. In the future, the uncertainty in projected CWA and CWD can be evaluated. The obtained results can be further analyzed for the evaluation of the impacts on catchment-scale water balance.

Author Contributions: Conceptualization, S.A.S. and S.S.; Data curation, S.A.S., S.S., A.S., G.S.A.S., A.A.B., A.A.F., E.-S.C., Y.A.A., B.M. and Z.M.Y.; Formal analysis, S.A.S., S.S., G.S.A.S., A.A.B., A.A.F., E.-S.C., Y.A.A., B.M. and Z.M.Y.; Investigation, S.A.S., A.S., G.S.A.S., A.A.B., B.M. and Z.M.Y.; Methodology, S.A.S., S.S., G.S.A.S. and A.A.F.; Project administration, Z.M.Y.; Resources, S.S., A.S. and A.A.B.; Software, S.A.S.; Supervision, S.S., G.S.A.S., A.A.F. and Z.M.Y.; Validation, A.S., G.S.A.S., A.A.B., A.A.F., E.-S.C., Y.A.A. and B.M.; Visualization, S.A.S., S.S., A.S., G.S.A.S., E.-S.C., Y.A.A., B.M. and Z.M.Y.; Writing-original draft, S.A.S., A.S., G.S.A.S., A.A.B., A.A.F., E.-S.C., Y.A.A., B.M. and Z.M.Y.; Writing-review and editing, A.S., A.A.F., E.-S.C. and Z.M.Y. All authors have read and agreed to the published version of the manuscript.

Funding: This research received no external funding.

Institutional Review Board Statement: Not applicable.

Informed Consent Statement: Not applicable.

Data Availability Statement: Data presented in the research.

Conflicts of Interest: The authors declare no conflict of interest.

\section{References}

1. Wang, X.-J.; Zhang, J.-Y.; Shahid, S.; Guan, E.-H.; Wu, Y.; Gao, J.; He, R.-M. Adaptation to climate change impacts on water demand. Mitig. Adapt. Strateg. Glob. Chang. 2016, 21, 81-99. [CrossRef]

2. Zhang, Q.; Li, J.; Singh, V.P.; Bai, Y. SPI-based evaluation of drought events in Xinjiang, China. Nat. Hazards 2012, 64, 481-492. [CrossRef]

3. Shahid, S. Impact of climate change on irrigation water demand of dry season Boro rice in northwest Bangladesh. Clim. Chang. 2011, 105, 433-453. [CrossRef]

4. Pour, S.H.; Wahab, A.K.A.; Shahid, S. Spatiotemporal changes in aridity and the shift of drylands in Iran. Atmos. Res. 2020, 233, 104704. [CrossRef]

5. Sun, S.K.; Li, C.; Wu, P.T.; Zhao, X.N.; Wang, Y.B. Evaluation of agricultural water demand under future climate change scenarios in the Loess Plateau of Northern Shaanxi, China. Ecol. Indic. 2018, 84, 811-819. [CrossRef]

6. Nautiyal, S.; Bhaskar, K.; Imran Khan, Y.D. Plant Biodiversity. In Biodiversity of Semiarid Landscape; Springer International Publishing: Manhattan, NY, USA, 2015; pp. 39-243.

7. Salman, S.A.; Shahid, S.; Afan, H.A.; Shiru, M.S.; Al-Ansari, N.; Yaseen, Z.M. Changes in Climatic Water Availability and Crop Water Demand for Iraq Region. Sustainability 2020, 12, 3437. [CrossRef] 
8. Ahmed, K.; Shahid, S.; Harun, S.b.; Wang, X.-j. Characterization of seasonal droughts in Balochistan Province, Pakistan. Stoch. Environ. Res. Risk Assess. 2016, 30, 747-762. [CrossRef]

9. Miyan, M.A. Droughts in asian least developed countries: Vulnerability and sustainability. Weather Clim. Extrem. 2015, 7, 8-23. [CrossRef]

10. Nashwan, M.S.; Shahid, S.; Dewan, A.; Ismail, T.; Alias, N. Performance of five high resolution satellite-based precipitation products in arid region of Egypt: An evaluation. Atmos. Res. 2020, 236, 104809. [CrossRef]

11. Almazroui, M.; Islam, M.N.; Jones, P.D.; Athar, H.; Rahman, M.A. Recent climate change in the Arabian Peninsula: Seasonal rainfall and temperature climatology of Saudi Arabia for 1979-2009. Atmos. Res. 2012, 111, 29-45. [CrossRef]

12. Nashwan, M.S.; Shahid, S.; Chung, E.S.; Ahmed, K.; Song, Y.H. Development of climate-based index for hydrologic hazard susceptibility. Sustainability 2018, 10, 2182. [CrossRef]

13. Salman, S.A.; Shahid, S.; Ismail, T.; Ahmed, K.; Wang, X.-J. Selection of climate models for projection of spatiotemporal changes in temperature of Iraq with uncertainties. Atmos. Res. 2018, 213, 509-522. [CrossRef]

14. Salman, S.A.; Shahid, S.; Ismail, T.; Ahmed, K.; Chung, E.-S.; Wang, X.-J. Characteristics of Annual and Seasonal Trends of Rainfall and Temperature in Iraq. Asia-Pac. J. Atmos. Sci. 2019, 55, 429-438. [CrossRef]

15. Pour, S.H.; Abd Wahab, A.K.; Shahid, S.; Wang, X. Spatial Pattern of the Unidirectional Trends in Thermal Bioclimatic Indicators in Iran. Sustainability 2019, 11, 2287. [CrossRef]

16. Pour, S.H.; Wahab, A.K.A.; Shahid, S. Spatiotemporal changes in precipitation indicators related to bioclimate in Iran. Theor. Appl. Climatol. 2020, 141, 99-115. [CrossRef]

17. El Kenawy, A.M.; Hereher, M.E.; Robaa, S.M. An Assessment of the Accuracy of MODIS Land Surface Temperature over Egypt Using Ground-Based Measurements. Remote Sens. 2019, 11, 2369. [CrossRef]

18. Brammer, H. Floods in Bangladesh: II. Flood Mitigation and Environmental Aspects. Geogr. J. 1990, 156, 158-165. [CrossRef]

19. Salman, S.A.; Shahid, S.; Ismail, T.; Chung, E.-S.; Al-Abadi, A.M. Long-term trends in daily temperature extremes in Iraq. Atmos. Res. 2017, 198, 97-107. [CrossRef]

20. Lelieveld, J.; Hadjinicolaou, P.; Kostopoulou, E.; Chenoweth, J.; El Maayar, M.; Giannakopoulos, C.; Hannides, C.; Lange, M.A.; Tanarhte, M.; Tyrlis, E.; et al. Climate change and impacts in the Eastern Mediterranean and the Middle East. Clim. Chang. 2012, 114, 667-687. [CrossRef]

21. Nam, W.-H.; Hayes, M.J.; Svoboda, M.D.; Tadesse, T.; Wilhite, D.A. Drought hazard assessment in the context of climate change for South Korea. Agric. Water Manag. 2015, 160, 106-117. [CrossRef]

22. Tsakiris, G.; Vangelis, H. Establishing a drought index incorporating evapotranspiration. Eur. Water 2005, 9/10, 3-11.

23. Verma, A.K.; Jha, M.K.; Mahana, R.K. Evaluation of HEC-HMS and WEPP for simulating watershed runoff using remote sensing and geographical information system. Paddy Water Environ. 2010, 8, 131-144. [CrossRef]

24. Surendran, U.; Sushanth, C.M.; Joseph, E.J.; Al-Ansari, N.; Yaseen, Z.M. FAO CROPWAT Model-Based Irrigation Requirements for Coconut to Improve Crop and Water Productivity in Kerala, India. Sustainability 2019, 11, 5132. [CrossRef]

25. Lu, J.; Sun, G.; McNulty, S.G.; Amatya, D.M. A comparison of six potential evapotranspiration methods for regional use in the southeastern united states. J. Am. Water Resour. Assoc. 2005, 41, 621-633. [CrossRef]

26. Thornthwaite, C.W. An Approach toward a Rational Classification of Climate. Geogr. Rev. 1948, 38, 55. [CrossRef]

27. Hui-Mean, F.; Yusop, Z.; Yusof, F. Drought analysis and water resource availability using standardised precipitation evapotranspiration index. Atmos. Res. 2018, 201, 102-115. [CrossRef]

28. Shiru, M.S.; Shahid, S.; Alias, N.; Chung, E.S. Trend analysis of droughts during crop growing seasons of Nigeria. Sustainability 2018, 10, 871. [CrossRef]

29. Onyutha, C. Long-term climatic water availability trends and variability across the African continent. Theor. Appl. Climatol. 2021, 146, 1-17. [CrossRef]

30. Biederman, J.A.; Scott, R.L.; Goulden, M.L.; Vargas, R.; Litvak, M.E.; Kolb, T.E.; Yepez, E.A.; Oechel, W.C.; Blanken, P.D.; Bell, T.W.; et al. Terrestrial carbon balance in a drier world: The effects of water availability in southwestern North America. Glob. Chang. Biol. 2016, 22, 1867-1879. [CrossRef]

31. Bussotti, F.; Pollastrini, M. Observing climate change impacts on european forests: What works and what does not in ongoing long-term monitoring networks. Front. Plant Sci. 2017, 8, 629. [CrossRef]

32. Poorter, L.; Bongers, F.; Aide, T.M.; Almeyda Zambrano, A.M.; Balvanera, P.; Becknell, J.M.; Boukili, V.; Brancalion, P.H.S.; Broadbent, E.N.; Chazdon, R.L.; et al. Biomass resilience of Neotropical secondary forests. Nature 2016, 530, 211-214. [CrossRef] [PubMed]

33. Li, M.; Xu, Y.; Fu, Q.; Singh, V.P.; Liu, D.; Li, T. Efficient irrigation water allocation and its impact on agricultural sustainability and water scarcity under uncertainty. J. Hydrol. 2020, 586, 124888. [CrossRef]

34. Malek, K.; Adam, J.C.; Stöckle, C.O.; Peters, R.T. Climate change reduces water availability for agriculture by decreasing non-evaporative irrigation losses. J. Hydrol. 2018, 561, 444-460. [CrossRef]

35. James, A.B.; Sullivan, S.; Nimmo, H.G. Global spatial analysis of Arabidopsis natural variants implicates 5'UTR splicing of LATE ELONGATED HYPOCOTYL in responses to temperature. Plant Cell Environ. 2018, 41, 1524-1538. [CrossRef] [PubMed]

36. Al-Najar, H.; Ashour, E.K. The impact of climate change and soil salinity in irrigation water demand on the Gaza Strip. J. Water Clim. Chang. 2013, 4, 118-130. [CrossRef] 
37. Brouziyne, Y.; Abouabdillah, A.; Hirich, A.; Bouabid, R.; Zaaboul, R.; Benaabidate, L. Modeling sustainable adaptation strategies toward a climate-smart agriculture in a Mediterranean watershed under projected climate change scenarios. Agric. Syst. 2018, 162, 154-163. [CrossRef]

38. De Silva, C.S.; Weatherhead, E.K.; Knox, J.W.; Rodriguez-Diaz, J.A. Predicting the impacts of climate change-A case study of paddy irrigation water requirements in Sri Lanka. Agric. Water Manag. 2007, 93, 19-29. [CrossRef]

39. Guo, Y.; Shen, Y. Agricultural water supply/demand changes under projected future climate change in the arid region of northwestern China. J. Hydrol. 2016, 540, 257-273. [CrossRef]

40. Rezaei Zaman, M.; Morid, S.; Delavar, M. Evaluating climate adaptation strategies on agricultural production in the Siminehrud catchment and inflow into Lake Urmia, Iran using SWAT within an OECD framework. Agric. Syst. 2016, 147, 98-110. [CrossRef]

41. Wada, Y.; Wisser, D.; Eisner, S.; Flörke, M.; Gerten, D.; Haddeland, I.; Hanasaki, N.; Masaki, Y.; Portmann, F.T.; Stacke, T.; et al. Multimodel projections and uncertainties of irrigation water demand under climate change. Geophys. Res. Lett. 2013, 40, 4626-4632. [CrossRef]

42. Chowdhury, S.; Al-Zahrani, M.; Abbas, A. Implications of climate change on crop water requirements in arid region: An example of Al-Jouf, Saudi Arabia. J. King Saud Univ. Eng. Sci. 2016, 28, 21-31. [CrossRef]

43. Zamani, R.; Akhond-Ali, A.M.; Roozbahani, A.; Fattahi, R. Risk assessment of agricultural water requirement based on a multi-model ensemble framework, southwest of Iran. Theor. Appl. Climatol. 2017, 129, 1109-1121. [CrossRef]

44. Azad, N.; Behmanesh, J.; Rezaverdinejad, V.; Tayfeh Rezaie, H. Climate change impacts modeling on winter wheat yield under full and deficit irrigation in Myandoab-Iran. Arch. Agron. Soil Sci. 2018, 64, 731-746. [CrossRef]

45. Yue, S.; Wang, C. The Mann-Kendall Test Modified by Effective Sample Size to Detect Trend in Serially Correlated Hydrological Series. Water Resour. Manag. 2004, 18, 201-218. [CrossRef]

46. Hamed, K.H. Trend detection in hydrologic data: The Mann-Kendall trend test under the scaling hypothesis. J. Hydrol. 2008, 349, 350-363. [CrossRef]

47. Kibaroglu, A.; Maden, T.E. An analysis of the causes of water crisis in the Euphrates-Tigris river basin. J. Environ. Stud. Sci. 2014, 4, 347-353. [CrossRef]

48. Abbas, N.; Wasimi, S.; Al-Ansari, N.; Nasrin Baby, S. Recent Trends and Long-Range Forecasts of Water Resources of Northeast Iraq and Climate Change Adaptation Measures. Water 2018, 10, 1562. [CrossRef]

49. Khosravi, K.; Daggupati, P.; Alami, M.T.; Awadh, S.M.; Ghareb, M.I.; Panahi, M.; Pham, B.T.; Rezaie, F.; Qi, C.; Yaseen, Z.M. Meteorological data mining and hybrid data-intelligence models for reference evaporation simulation: A case study in Iraq. Comput. Electron. Agric. 2019, 167, 105041. [CrossRef]

50. Oleiwi, S.; Jalal, S.; Hamed, S.; Ozgur, S.; Zaher, K.; Yaseen, M. Precipitation pattern modeling using cross-station perception: Regional investigation. Environ. Earth Sci. 2018, 77, 709.

51. Yaseen, Z.M.; Al-Juboori, A.M.; Beyaztas, U.; Al-Ansari, N.; Chau, K.-W.; Qi, C.; Ali, M.; Salih, S.Q.; Shahid, S. Prediction of evaporation in arid and semi-arid regions: A comparative study using different machine learning models. Eng. Appl. Comput. Fluid Mech. 2019, 14, 70-89. [CrossRef]

52. Sayl, K.N.; Muhammad, N.S.; Yaseen, Z.M.; El-shafie, A. Estimation the Physical Variables of Rainwater Harvesting System Using Integrated GIS-Based Remote Sensing Approach. Water Resour. Manag. 2016, 30, 3299-3313. [CrossRef]

53. Simmons, J.L. Agricultural development in Iraq: Planning and management failures. Middle East J. 1965, 19, 129-140.

54. Salman, S.A.; Shahid, S.; Ismail, T.; Rahman, N.b.A.; Wang, X.; Chung, E.S. Unidirectional trends in daily rainfall extremes of Iraq. Theor. Appl. Climatol. 2018, 134, 1165-1177. [CrossRef]

55. Salman, S.A.; Shahid, S.; Ismail, T.; Al-Abadi, A.M.; Wang, X.-J.; Chung, E.S. Selection of gridded precipitation data for Iraq using compromise programming. Measurement 2019, 132, 87-98. [CrossRef]

56. Vicente-Serrano, S.M.; Beguería, S.; López-Moreno, J.I.; Angulo, M.; El Kenawy, A. A New Global 0.5 Gridded Dataset (19012006) of a Multiscalar Drought Index: Comparison with Current Drought Index Datasets Based on the Palmer Drought Severity Index. J. Hydrometeorol. 2010, 11, 1033-1043. [CrossRef]

57. Vicente-Serrano, S.M.; Beguería, S.; López-Moreno, J.I. A Multiscalar Drought Index Sensitive to Global Warming: The Standardized Precipitation Evapotranspiration Index. J. Clim. 2010, 23, 1696-1718. [CrossRef]

58. Brouwer, C.; Heibloem, M. Irrigation Water Management: Irrigation Water Needs; FAO: Rome, Italy, 1986 ; Volume 3.

59. Doorenbos, J.; Pruitt, W.O. Guidelines for Predicting Crop Water Requirements; Irrigation and Drainage Paper No. 24; FAO: Rome, Italy, 1977.

60. Qutbudin, I.; Shiru, M.S.; Sharafati, A.; Ahmed, K.; Al-Ansari, N.; Yaseen, Z.M.; Shahid, S.; Wang, X. Seasonal Drought Pattern Changes Due to Climate Variability: Case Study in Afghanistan. Water 2019, 11, 1096. [CrossRef]

61. Wilcoxon, F. Individual comparisons of grouped data by ranking methods. J. Econ. Entomol. 1946, 39, 269-270. [CrossRef]

62. Rey, D.; Neuhäuser, M. Wilcoxon-signed-rank test. Int. Encycl. Stat. Sci. 2011. [CrossRef]

63. Shen, Y.; Li, S.; Chen, Y.; Qi, Y.; Zhang, S. Estimation of regional irrigation water requirement and water supply risk in the arid region of Northwestern China 1989-2010. Agric. Water Manag. 2013, 128, 55-64. [CrossRef]

64. Ragab, R.; Prudhomme, C. Climate change and water resources management in arid and semi-arid regions: Prospective and challenges for the 21st century. Biosyst. Eng. 2002, 81, 3-34. [CrossRef]

65. Li, C.; Cai, Y.; Qian, J. A multi-stage fuzzy stochastic programming method for water resources management with the consideration of ecological water demand. Ecol. Indic. 2018, 95, 930-938. [CrossRef] 